\title{
Beringian Wolf
}

You I couldn't find, until I saw,

on Main Street, through clean glass,

the man with the tall broad back,

fixed rectangle of moving poise.

He was the wolf, an ecomorph

off course on the Cordilleran ice sheet.

Or the slim woman, hand in raincoat pocket, with waist-belted confidence I've never had.

Or the man dressed for rustic blending

on a false-fronted road: bark jacket,

lichen trousers. The lean are on the streets.

The fat are in the coffee shops, grasping lattés;

we're watching skinny wolf hips

and broad-mouthed skulls grappling chatter.

That man, by the truck, black jacket,

blue jeans and sneakers, has never

had to tug his sweater down over his arse,

has never hoped no one's noticed he's worn

the same top to work two days in a row.

He's never believed he's a subspecies

that needs to be extinct and, kissing,

pushed away a pelvis. 